\title{
CRISIS What CRISIS? THE RECOGNITION ISSUE AND CANADIAN IDENTITY CRISES
}

\author{
Jack Jedwab
}

During his 1996 swearing-in ceremony, Québec Premier Lucien Bouchard spoke about the need for "a renewed recognition on the northern part of the continent of two profoundly different peoples." Explicitly referring to Québecers and Canadians, he added that these two peoples would soon have to decide upon their respective destinies. Those who are attached to both Québec and Canada will no doubt have difficulty situating themselves within the Premier's observation. Still, his characterization remains representative of the way in which the national unity debate and the identity crisis that underlies it are often described by those who advocate Québec sovereignty. It also points to the extent to which an important number of Québecers - to be specific the province's francophones - do not feel a strong attachment to Canada.

Until recently, many Québecers have cast the Canadian identity problem in terms of the ongoing - and generally unsuccessful - effort to acknowledge the binational or bicultural character of the federation. Failing such recognition, sovereignists in particular believe that the best way to resolve the troubling ambiguity that presumably arises from being both a Québecer and a Canadian, and the ensuing political consequences, is for the "two entities" to say goodbye to one another. Some federalists also believe that such a political divorce represents the solution to our identity crisis and thus to the broader unity issue. Indeed, a former provincial

Lucien Bouchard, "Discours d'assermentation prononcé par le premier ministre du Québec" (Acceptance speech at swearingin ceremony, January 29, 1996), online: Gouvernement du Québec <http://www.premier.gouv.qc.ca /general/discours/archives_discours/1996/janvier/dis1996012 9.htm $>$ [translated by author].
Liberal politician made the case for the rest of Canada divesting, or ridding, itself of Québec. Reed Scowen maintains that the inability to satisfy what he describes as the never-ending demands of Québec nationalists justifies such a course of action. ${ }^{2} \mathrm{He}$ contends that by liberating itself from Québec's ethnic nationalism, the rest of Canada would no longer be subjected to the identity-based conflict that it perpetually generates. It is an idea that likely reflects Scowen's growing exasperation and that of a number of other federalists notably those outside Québec - with the threat of separation. Whatever their political orientation, advocates of a split between Québec and the rest of Canada significantly minimize the identity problems that will arise in the two or more reconstituted entities.

As regards identity issues, for some time many federalists and sovereignists have attributed their respective plights to one another. They stress the divided national loyalties stemming from the attachment to two sociological and/or political nations. This view of the Canadian identity crisis has heavily influenced the type of solutions brought forth by government. The most popular example has been the call by an important number for the recognition of the English and French populations of the country as its two founding nations or peoples. Canada's Royal Commission on Bilingualism and Biculturalism of the early 1960s was for many, a laudable attempt to achieve this objective. During the 1960s, certain Québec politicians sought acknowledgement of the equality of the two founding groups. In his book,

Reed Scowen, Time to Say Goodbye: The Case for Getting Québec Out of Canada (Toronto: McClelland \& Stewart Inc., 1999). 
Equality or Independence, the late Québec Premier Daniel Johnson Sr. called upon the recognition by Canada of the "equality of its two linguistic and cultural communities, its two founding peoples, its two societies, its two nations in the sociological sense of the term." ${ }^{3}$ As one of Québec's most prominent sociologists put it, Johnson's formulation "could not have been clearer."4

Since the 1970s, the recognition of Québec's particular status has perhaps been the dominant approach to addressing the identity component of the national unity issue (this has also been referred to as conferring special status on Québec). Since that decade, the focus has moved away from the recognition of Canada's French fact to the constitutional enshrinement of the specificity of Québec with a focus on its linguistic and cultural characteristics. The rest of Canada recognizing Québec's distinct character (as was attempted with the Meech and Charlottetown Accords) does not explicitly require the recognition of two societies in the country. Indeed, it may be argued that this approach is not fundamentally dualistic in that there has been no direct acknowledgement of the particular attribute of the rest of Canada. As we shall observe, certain federalists and sovereignists have recently attempted to address this presumed omission by insisting that the rest of Canada constitutes a nation and that it is part of a multinational federation. In what follows, we will briefly examine the recent efforts at status recognition as a solution to the national question and the latest proposals aimed at responding to Canada's identity crisis.

Apart from efforts aimed at status recognition, federal governments have for nearly four decades developed at least two other solutions to dealing with the Québec-Canada conflict. Another approach might be described as "inclusion"; that is, the effort made to increase the presence of francophone Canadians in the federal decisionmaking apparatus. Perhaps the best example of this has involved the integration of francophones into the Canada's civil service so that their representation be equal to their overall share of the Canadian population. Finally, the federal

\footnotetext{
3 As cited in Fernand Dumont, Raisons Communes (Québec: Boréal, 1995) at 38 [translated by author].

4 Ibid.
}

government has attempted to reinforce regional identities via the transfer or decentralization of jurisdiction to the provinces. The idea behind this was to give the provinces a greater sense of autonomy. In the case of Québec, a prime example of this is to be found in the Ottawa-Québec immigration agreements of 1978 and 1990 (otherwise known as the Cullen-Couture and the McDougall-Gagnon-Tremblay agreements). ${ }^{5}$ Such transfer of authority can often have an asymmetrical dimension wherein one province may acquire jurisdiction in an area not extended to the other provinces. As approaches to the unity issue, status recognition, inclusion and the reinforcing of regional identities are very often interrelated. For example, from the perspective of the federal government, it may be argued that both inclusion and recognition were addressed in the conferring in 1969 of official status on the English and French languages. ${ }^{6}$ Others may counter that the federal Official Languages Act did not sufficiently take into account the desire on the part of the provinces to strengthen regional identities in regard to language issues. ${ }^{7}$

While there may be debate over the relative merits of the three approaches, many observers will agree that the least successful of these approaches has been the effort to recognize Québec's distinct character. As former Québec Senator Claude Castonguay has remarked, the failures in this regard (i.e. Meech and Charlottetown) have only fuelled identity and unity crises and subsequently weakened the resolve of many Québecers to stay in the federation.

Some see the evolution from an English/French to a Québec/Canada recognition model as reflecting a shift from linguistic and cultural considerations to geographic ones. Still, this evolution reflects the overwhelming concentration of French-speakers in Québec and English-speakers outside the province. Whether recognition models are rooted in geography or language, these formulas inevitably confront the phenomenon of regional attachments, diversity

Immigration Canada, Canada-Québec Accord (Relating to Immigration and Temporary Admission of Aliens) (Hull: Public Affairs Centre, 1991).

Official Languages Act, S.C. 1968-1969, c. 54.

Jack Jebwab, "La crise identitaire québécoise ne se réglera pas avec l'indépendance” La Presse (28 September 1999) B3. 
and multiple identities. The rise of multiple expressions of identity and the increased mixing or "métissage" of the population represent a fundamental dilemma for all those who continue to insist upon bi-national solutions to Canada's collective conundrum. In short, the boundaries or frontiers that protect linguistic and regional identities are not as rigid as some may assume.

The constant growth and diversification of the population both outside and within Québec have made it increasingly more difficult to reconcile linguistic and cultural differences. They have created equally complex issues within Québec in regard to recognition, inclusion and regional identification within that province. Recently, Québec sovereignists have encountered problems that in many ways resemble those that federalists have confronted in responding to Canadian identity questions.

It is hard to imagine that previous experiments with recognition formulas will succeed in the near future. Some sovereignists and a small group of federalists have nonetheless been crafting a new proposal that they believe can reconcile the identity needs of Québec and Canada (often referred to as "the rest of Canada" or "English Canada"). The supposed new model might be described as adding an additional "nation" to the bi-national recognition approach. Referring to their proposal as the multinational federation, its proponents contend that Canada is unwilling to acknowledge its multinational character, namely the presence of the English Canadian, Québecois and Aboriginal nations. ${ }^{8}$ The idea that Canada recognize itself as a multinational federation is a formula that is as flawed as the bi-national concept. In effect, it is based on three divergent notions of nationhood that would be extremely difficult to reconcile. Indeed, such a multinational, or to be precise, tri-national pact, is unlikely to resolve the complex identity needs of the federation.

\footnotetext{
See for example Will Kymlicka, "Multinational Federalism in Canada: Rethinking the Partnership" in Roger Gibbons \& Guy Laforest, ed., Beyond the Impasse: Toward Reconciliation (Montreal: IRPP, 1998) 15 and Michel Sarra-Bournet et al., Manifeste des intellectuels pour la souveraineté (Montreal: Éditions Fides, 1995).
}

\section{HISTORIC RECOGNITION: THE ROYAL COMMISSION ON BILINGUALISM AND BICULTURALISM}

Rooted in Canada's history, some will trace the origins of the recognition effort as far back as 1774 with the adoption of the Québec $A c t^{9}$ in the aftermath of the British Conquest of New France. The Act recognized the right to profess the Catholic faith, the French language and the civil law tradition. Yet others will direct us to the Confederation agreements and the debate over whether they constituted a compact between English and French cultures or a pact between the contracting provinces of the 1867 arrangement. It is worth noting that whatever one's position is on this debate, it would be hard to make the case that the 1867 agreement was a "two-way" deal between Québec and the rest of Canada.

It may be contended that the first major attempt to address the Canadian identity question in the twentieth century emerged with the Royal Commission on Bilingualism and Biculturalism (RCBB). ${ }^{10}$ Its deliberations remain a crucial reference for those who wish to understand the identity debates of the last four decades of the twentieth century. During the early 1960s, the RCBB defined certain parameters that continue to influence the contemporary discussion over the recognition of the French fact in Canada.

The RCBB reported that relations between English and French Canadians had deteriorated to a point where the two groups' will to live together was in jeopardy. Canadians were thus warned that while they might not be fully conscious of it, their nation was perhaps passing through its greatest crisis. In an effort to prevent this imminent disaster, the Royal Commission was mandated to inquire into and report on the existing state of bilingualism and biculturalism in Canada and to recommend measures whereby Canadian Confederation could be developed on the basis of an equal partnership between the two founding "races"- later replaced by the word "peoples." While in the process of attempting to forge a deal between its founders, the

\footnotetext{
(U.K.), 14 George III, c. 83.

10 Canada, Report of the Royal Commission on Bilingualism and Biculturalism, General Introduction: The Official Languages, vol. 1 (Ottawa: Queen's Printer, 1967).
} 
Royal Commission was also instructed to consider the contribution made by other immigrant and ethnic groups to the cultural enrichment of Canada.

It was commonly accepted that the notion of founding peoples was based on some combination of ethnic and linguistic characteristics. The Royal Commission sought an equal "partnership" or "biculturalism" between English and French Canadians in a manner that would ultimately supercede the country's provincial boundaries. But the cultural pact was difficult to achieve in a society with an increasingly diverse ethnic composition and regional concentration in the two major linguistic groups. There seemed little hope of legislating a partnership between two founding races or peoples. Indeed, underlying this arrangement was the idea that there were two relatively monolithic ethnolinguistic groups in Canada. Many Canadians of origins other than British or French who objected to the Royal Commission's initial pursuit of an "equal partnership between the two founding peoples" did so because they felt that it would bestow a particular status upon the charter groups that might place the others at a disadvantage.

Prior to the establishment of the RCBB, the federal government had not achieved much success in addressing the concerns of linguistic and ethnic minorities on those occasions when it had been called upon to intervene. Since Confederation, political and demographic realities reinforced the authority of provincial jurisdictions and ensured that they be charged with matters pertaining to minority language issues, notably in the school system. Regrettably, in a number of instances, the behavior of many provincial leaders outside of Québec as regards such concerns was far from exemplary and the commissioners thus viewed themselves as attempting to correct a historic wrong. During the 1960 s, the federal authorities realized that there was a growing urgency to significantly re-evaluate the role of government with respect to language and cultural issues, particularly as regards minority communities. In doing so, Canada undertook a major political challenge with potentially significant ramifications for Canadian unity.

There was confusion as to just how the state would go about implementing biculturalism. From the debates of the RCBB, it never seemed clear beyond the acquisition of the two languages (French and English), how this culturally dualistic objective would be attained. As ambiguously defined by the Royal Commission, the term biculturalism referred to the co-existence of two "distinct" ways of life which "obviously had much in common." Although it took for granted what in this case was "distinct" or "common," the Royal Commission claimed that:

Just as bilingualism should not lead to a blend of two languages so Canada's cultural duality cannot be taken to mean a mixture of the two cultures; each has its own existence.... Culture is to the group rather what personality is to the individual: it is rare for a person to have two personalities or two styles of living at the same time. ${ }^{11}$

In contrast to the description offered by the Royal Commission, then Prime Minister, Lester B. Pearson, argued that biculturalism did not imply that the nation's social fabric would be characterized by the co-existence of two separate cultural societies. In his 1964 Throne-Speech, Pearson stated that "for one thing English and French cultural are not and cannot be separate and distinct from each other or other cultural strains in Canada." He added that "there should be no pressure on one to absorb the other, but they should develop along with each other, each, I hope, influencing the other." 12

The "cultural" survival of French Canadians was at the very core of the debates of the 1960s. While certain Canadians spoke of an "equal partnership" between English and French Canadians on a national scale, others felt that the future of the French language and culture required that all energies be focused on the situation in Québec. As the RCBB embarked on its mission, a then provincial Liberal Cabinet Minister, René Lévesque, aptly expressed the latter view. In 1963, he stated that:

We must not mislead others into believing that biculturalism is a basic goal or value. It is infinitely more important to make Québec progressive, free and strong, than to devote the best of our energies to

\footnotetext{
Ibid. at xxxi [emphasis in original].

James Stewart, "National unity plea earns PM ovation" Montreal Star (21 February 1964) 1 at 4.
} 
propagating the doubtful advantages of biculturalism. Moreover, if the French language is to be respected that will depend upon all the vigor, on the economic and political importance of Québec. This must become and must remain our first concern, by far out most decisive and constant preoccupation. ${ }^{13}$

\section{LANGUAGE, IDENTITY AND RECOGNITION}

After considerable deliberations, the significant initiatives to emerge in the aftermath of the report of the RCBB were the Official Languages Act (1969) and the federal policy on multiculturalism (1971). Thus, in the end the federal government opted for a policy of official languages but did not enshrine in law that there were two official cultures in Canada. Reconciling linguistic duality and cultural diversity in this way was not endorsed by Québec's political leaders of the day nor did it meet with the approval of the leaders of certain ethno-cultural minorities outside that province.

During the 1970s, the rejection of biculturalism returned to haunt the federal government. Originally intended as a protest against multiculturalism, the renewed support for biculturalism seemed to reinforce the idea that only the Québec state could provide substantive guarantees for the preservation of French Canadian culture. In the early years of the decade, then prominent journalist, Claude Ryan, argued that if Canada had any future, it would have to be based on the equality of the "two founding peoples. ${ }^{" 14}$ This required that every Canadian obtain a working familiarity with the two official languages and become acquainted with the culture of the two "leading" communities. ${ }^{15}$ Ryan concluded that the effort to resolve the question of linguistic parity without redressing cultural inequalities, would be

13 René Levesque, "A Strong Québec Takes Precedence Over a Bicultural Canada" (originally published in Le Devoir, 5 July 1963) trans. in Frank Scott \& Michael Oliver, eds., Quebec States Her Case: Speeches and Articles from Québec in the Years of Unrest (Toronto: MacMillan, 1964) at 144-145.

14 Claude Ryan, "Canada: Bicultural or Multicultural?" in Howard Palmer, ed., Immigration and the Rise of Multiculturalism (Toronto: Copp Clark Publishing, 1975) 147 at 148.

15 Ibid. "have said good-bye, once and for all, to the possibility of a united country." 16

Somewhat similar declarations were made by Québec Premier Robert Bourassa in his reaction to the federal bilingual/multicultural initiative. Bourassa argued that the policy of multiculturalism was highly unsuited to Québec "where the predominant population group is linguistically and culturally French, where a large minority is linguistically and culturally English, and where there are many minorities having other linguistic and cultural origins." ${ }^{.17}$ The Premier claimed that the federal government's policy was founded on a questionable dissociation of culture from language.

Both Ryan and Bourassa concluded that the multicultural approach adopted by the federal government contradicted the idea of attaining equality between the two founding peoples through the development of a bilingual and bicultural nation. Under the circumstances where the federal government presumably expressed the intention to assume responsibility for the promotion of all cultures, Bourassa concluded that "Québec must take on within its own territory the role of the prime defender of the French language and culture ... in North America and it proposes to do this with all the means at its disposal. This does not mean that there will be the slightest discrimination against other cultures." $" 18$

\section{MAKING THINGS OfFICIAL}

The strategic approach adopted by Québec to address its linguistic and cultural concerns in some ways resembled that pursued by the federal authorities. Whereas the federal government created a commission on bilingualism and biculturalism in the early part of the decade, in the late 1960s the Québec government established a commission of inquiry to look into the position of the French language in the province. In 1974, it adopted legislation making French the only official language of Québec. ${ }^{19}$ Under Bill 22, however, a number of references to the English language were designed to demonstrate a continued attachment to some degree

\footnotetext{
Ibid.

17 Robert Bourassa, "Objections to Multiculturalism" in Palmer, ed., supra note 14,151 at 152 .

18 Ibid.

19 Official Language Act, S.Q. 1974, c. 6 (also known as Bill 22).
} 
of linguistic duality. In 1977, the Parti Québécois government adopted the Charter of the French Language $^{20}$ (Bill 101), which offered less recognition of the English language in Québec than did Bill 22. As one analyst noted, where Bill 101 used the term "languages other than French," Bill 22 specifically referred to the English language. ${ }^{21}$ Perhaps ironically, some regard the approach to languages other than French as stipulated in sections of Bill 101 as being more classically pluralistic than the previous legislation. Québec's political leaders believed that the bilingual-multicultural framework adopted by the federal authorities would result in the continued expression of multi-ethnicity in the English language both outside of Québec and, for that matter, within the province. By consequence, the unilingual-pluralistic framework of Bill 101 was viewed as parallel to the federal model in a manner that would address Québec's concerns over the future of the French language. Thus, Bill 101's chief architect Camille Laurin explained that:

[I]n order to live together in the same nation, the various ethnic groups which make it up must be able to speak and understand each other. Hence, a national language and common culture are useful, although they do not preclude the continued use of ethnic languages and maintaining of individual cultures. ${ }^{22}$

During the 1980s, the recognition effort evolved away from the idea of a bi-cultural arrangement based upon English-French ethno-national dualism to the establishment of a formula that might reconcile Québec and the rest of Canada. This was prompted by the growing affirmation of Québec nationalism which culminated in the election of the Parti Québécois in 1976, the adoption of the Charter of the French Language in the following year, and, in 1980, a referendum on Québec sovereignty and an association with Canada. One year after the referendum defeat of the sovereignists, the federal government repatriated the Constitution and, with the exception of Québec, all the provinces signed on. Québec political leadership protested that it had been excluded from the process. In 1982, the federal

20 R.S.Q. 1977 , c. C-11.

21 William D. Coleman, "From Bill 22 to Bill 101: The Politics of Language under the Parti Québécois" (1981) 14 Canadian Journal of Political Science 459 at 465.

22 Camille Laurin, "Ethnic Minorities in the New Québec" (1978) 10:1 Canadian Ethnic Studies 5. government adopted a Charter of Rights and Freedoms which included the recognition that: "English and French are the official languages of Canada and have equality of status and equal rights and privileges as to their use in all institutions of the Parliament and government of Canada., ${ }^{, 23}$ It is apparent that since Confederation several recognition formulas have attempted to address the issue of linguistic identity.

\section{From MeECh to ChaRLotTetown}

In the late 1980s, the federal government revised its Official Languages Act and added to the existing articles of that law a commitment to "enhancing the vitality and supporting the development of English and French linguistic minority communities, as an integral part of the two official language communities of Canada, and to fostering full recognition and use of English and French in Canadian society." 24 The same law also "recognizes the importance of preserving and enhancing the use of languages other than English and French while strengthening the status and use of the official languages. ${ }^{25}$ The vitality clause was adopted in the very midst of the debate over the constitutional accord that was aimed at bringing Québec into the fold.

In June 1987, the Meech Lake Accord stated prominently that any interpretation of the Constitution must recognize that Québec forms a distinct society within Canada, and affirmed the role of the Québec government and legislature "to preserve and promote the distinct identity of Québec." ${ }^{26}$ Although the emphasis was placed upon protection for a francophone population not confined to, but concentrated in Québec, the distinct society clause also recognized the presence of Québec anglophones as part of a fundamental characteristic of Canada; namely, its English-French duality.

23 Canadian Charter of Rights and Freedoms, Part I of the Constitution Act, 1982, s.16(1), being Schedule B to the Canada Act 1982 (U.K.), 1982, c. 11.

24 Official Languages Act, R.S. 1988, c. 38, Preamble

25 Ibid.

26 Meech Lake Constitutional Accord, 3 June 1987 (text settled at second First Minister's Conference in the Langevin Block, Ottawa), online: The Solon Law Archive <http://www. solon.org/Constitutions/Canada/English/Proposals?MeechLa ke.html>. 
The Accord stipulated that the Constitution be interpreted in a manner consistent with the recognition of the existence of French-speaking Canadians centered in Québec but also present elsewhere in Canada, and English-speaking Canadians concentrated outside Québec but also present in Québec. This would constitute a fundamental characteristic of Canada as would the recognition that Québec constitutes a distinct society within Canada. Furthermore, the role of the legislature and the Government of Québec to preserve and promote the distinct identity of Québec was affirmed. Set to go into effect in June 1990 approximately one year to term the Accord lost its near unanimous approval when it confronted vigorous opposition from certain provincial leaders in Manitoba, New Brunswick and Newfoundland.

Much like the confusion over certain concepts during the RCBB, analysts attributed various, and sometimes contradictory, meanings to the distinct society clause. A perceptive editorialist noted that it was not possible for Québecers to be sure of the implications of their distinctiveness. One commentator attributed both the success and potential problems with the Accord to its imprecision.

Yet one authority remarked: "il n'est évidemment pas question de transcrire une théorie sociologique dans un texte juridique, d'énumérer tous les traits qui nous distinguent. ${ }^{, 27}$ Constitutional expert Gérald Beaudoin claimed that Meech Lake's declaration of distinctive merely translated a state of fact into law by reaffirming a fundamental element of Canadian dualism. ${ }^{28}$ While linguistic duality is certainly an important characteristic of Canada, Beaudoin still regarded cultural duality, the prevailing view of the $1960 \mathrm{~s}$, as the basis upon which adjudicators should make decisions affecting the entire society. He rejected the idea of enumerating components of the distinct society that he believes would make interpretation of the cause too restrictive. Beaudoin concluded that "si l'on exepte la langue, la culture, le Code civil qui sont des constantes, la spécificité du Québec peut varier en intensité d'une époque à l'autre: confessionalité des écoles, valeurs sociales, système d'éducation.

27 Claude Morin, "Bourassa et les lendemains piégés" Le Devoir (6 December 1988) 7.

28 See Gérald Beaudoin, “Avis D’Experts, D’Analystes et de Commentateurs" in Le Devoir, ed., Le Québec et le Lac Meech (Montréal: Guérin, 1987) 75 at 79.
Allons-nous à chaque génération ajouter ou retrancher à la déclaration sur la société distincte?"29

Some observers attribute the rejection of the Meech Lake Accord to the invoking of the notwithstanding clause in the aftermath of the Supreme Court judgement which declared that the unilingual commercial signs provisions of the Charter of the French language were in violation of the right of freedom of expression. ${ }^{30}$ The Parti Québécois' constitutional negotiator of the immediate post referendum period, Claude Morin, argued that English Canada was only prepared to accept Québec's distinctiveness when it behaved in a manner that was not distinctive. He suggested that English Canada regarded the clause as a symbol and merely recognized the French language and certain customs as rendering the society different. Morin contended that:

[Q]ue ses signataires savaient qu'ils signaient un document où l'on mentionnait que le Québec formait une société distincte, ils admettaient logiquement du même coup que celui-ci pourrait disposer de la latitude voulue pour se servir des moyens appropriés en vue de sauvegarder et d'affirmer son identité, surtout en matière linguistique. ${ }^{31}$

Morin urged the rest of Canada not to assume that the distinct society was symbolic rather than substantive. He argued that culturally and demographically, Canada's population is made up of two viable groups, the English Canadians - joined by most new Canadians - and the French Canadian group centered in Québec. The latter division, Morin suggests, describes the typical tendency of Canadian federalism and "if we do not take it into consideration we cannot understand either federalprovincial tension in the country or the history of Canada altogether., 32

The failure of the Meech Lake Accord did not put an end to the search for a formula that would permit Québec to sign the Canadian Constitution.

\footnotetext{
$29 \quad$ Ibid. at 80.

30 Ford v. Québec (Attorney General), [1988] 2 S.C.R. 712, online: CanLII <http://www.canlii.org/ca/cas/scc/ 1988/1988scc94.html $>$.

31 Morin, supra note 27.

32 Claude Morin, Québec versus Ottawa: The Struggle for SelfGovernment, 1960-1972 (Toronto: University of Toronto Press, 1976) at 150.
} 
Not long after the failure of the Meech Lake Accord, a new deal was negotiated by the federal and provincial political leaders. The 1992 Charlottetown Accord proposed the amending of the Constitution Act in a manner consistent with eight fundamental characteristics in what was referred to as a "Canada Clause." 33 The Accord stipulated that Québec constitutes a distinct society within Canada that includes a French-speaking majority, a unique culture and a civil law tradition. Like its predecessor, the role of the legislature and the Government of Québec to preserve and promote the distinct identity ofQuébec was affirmed. But the Accord also called for the Aboriginal peoples of Canada to have the right to promote their languages, cultures and traditions, to ensure the integrity of their societies, and stipulated that their governments constitute one of the three orders of government in Canada. Amongst other identity traits included in the Canada Clause were commitments to: the vitality and development of official language minority communities throughout Canada; racial and ethnic equality in recognition of the contribution of citizens from many lands to the building of a strong Canada; the equality of male and female; respect for individual and collective human rights; and, a confirmation of the equality of the provinces with a recognition of their diverse characteristics. The Accord was to be submitted to the Canadian population for approval in a nationwide referendum where a majority of residents of each province would have to vote in favour. Thus, a majority of residents of each province, as opposed to a majority of Canadians, would have to agree on what might be described as the Canadian identity clause. In the end, the Accord was rejected by nearly every province in the country.

The Meech Lake and Charlottetown Accords respectively attempted to address Québec's identity needs. In each case, certain non-Québecers sought recognition for aspects of their identity, fearing that inequities might arise between Québec and those groups and/or regions whose particular traits were not acknowledged in the Canadian Constitution. Aboriginal peoples seemed especially preoccupied by the idea that they would not obtain satisfactory constitutional recognition. These efforts at mutual

\footnotetext{
33 The Charlottetown Accord, 28 August 1992, online: The Solon Law Archives http:/www.solon.org/Constitutions/Canada/ English/Proposals/CharlottetownConsensus.html>.
}

recognition failed, resulting in a resurgence of nationalist sentiment amongst Québec's French population.

\section{REDEFINING OURSELVES}

On the question of identity, in their prereferendum manifesto for a sovereign Québec, a leading group of intellectuals argued that Québecers form a people and have for some time made efforts to operate within the Canadian federalist framework. But Canada refuses to recognize Québec's status as such and give it the tools it needs to develop fully. It is necessary to take note of the incapacity of Canada to see itself as a multinational state. ${ }^{34}$ In order to get "beyond the impasse," one federalist, Will Kymlicka, argues that "the real threat to Canada's long-term stability remains the failure to reach a satisfactory arrangement with Canada's non-immigrant national minorities - namely, the Québecois and the Aboriginal peoples." 35 Philosopher Will Kymlicka claims that we need to accept that Canada is and will remain a multinational state a federation of peoples. In effect he is proposing a model for recognition of Canadian identities that differs from the formulas seen thus far. In a recent essay, James Tully echoes the view put forth by Kymlicka. He notes that in multinational federations like Canada, it is essential to accord the status of peoples to the Québecers and the Aboriginal population and offer them a right to what he calls "internal self-determination." ${ }^{\text {"36 }}$ Only in this manner, he adds, will these two groups ever feel a greater attachment to a multinational Canada. Unlike Kymlicka, in Tully's multinational federation, there are only two peoples or nations. In fact, Tully's notion might be described as a new version of the two-nations theory.

In the multinational Canada proposed by Kymlicka, English-speaking Canadians must be persuaded that they have common interests as a linguistic community. These interests, he adds, are relatively similar to those of francophones or Aboriginals. Ironically, Kymlicka points to two

\footnotetext{
Michel Sarra-Bournet et al., supra note 8 at 80- 81 .

Kymlicka, supra note 8 at 15.

36 James Tully, "Liberté et dévoilement dans les sociétés multinationals" (1999) 2 Globe: Revue internationale d'études québecoises 1 .
} 
major obstacles to his own idea and, for that matter, to the framework put forward by James Tully. First, Kymlycka acknowledges that "English-speaking Canadians have little or no sense of group identity - little or no sense that they form a distinct community within Canada." 37 (I would argue that language is not the dominant marker of identity for English-speakers with perhaps the exception of those who live in Québec). Therefore, they must be convinced that they have similar "national" identity needs, something which Kymlicka acknowledges has virtually no popular resonance amongst Englishspeaking Canadians. But there are a number of other equally serious matters that would have to be overcome to attain the recognition of the three nations. Kymlicka, and to a somewhat lesser extent, Tully, pay little attention to the presence of francophones outside of Québec and Englishspeaking Canadians within the province.

In short, the proposal advanced by Kymlicka and Tully is based on three different notions of nationhood that would be difficult to reconcile. The "Québecois" nation would be based on the territory and the current boundaries. The rest of Canada's national status would be based on the sharing of the English language, and the Aboriginals would, in theory, possess nations within these nations. Undoubtedly, were such a dubious formula implemented, the political value of "national" status would vary considerably.

Michel Seymour rightly notes that when Kymlicka uses the term "Québécois" in French, it is synonymous with francophone and thus not inclusive of other communities that reside in Québec. ${ }^{38}$ It is legitimate to ask to what "nation" the English-speakers of Québec belong, not to mention those of neither English nor French mother tongue who may find themselves nationless. Pursuing the logic of language alone as the basis for nationhood leads to the conclusion that all English-speakers, including those in Québec, belong to the anglophone or Canadian nation, and all francophones, including those outside Québec, belong to the francophone nation. In Kymlicka's three-nation pact, is membership to be defined by mother tongue, the language used at home or the

Kymlicka, supra note 8 at 29.

38 Michel Seymour, Nationalité, citoyenneté et solidarité (Montréal: Liber, 1999) at 165. language people use in public life? How does the three-nation theory take into account dual or multiple attachments of members of each "nation"?

Yet another problem with the recognition of the sociological dimension of nationhood is that many in Canada do not distinguish it from the political nation. For many English-speaking and French-speaking Canadians, the idea of "la nation" and "le pays" are synonymous. Indeed, it is hard to describe the rest of Canada as constituting one nation. Were Québec to split, the rest of Canada might choose to reconstitute itself as three of four nations, thereby casting serious doubt upon the idea of three nations, though, ironically, not dismissing some form of multinationalism. Political scientist Alan Cairns has argued that "the search for the ROC's reconstitution after Quebec's departure would, other things being equal, likely privilege provincial governments, especially those of the wealthier provinces, and thus lead to a more fragmented, provincialized successor state than would be probable if haste could be avoided. It might even result in two or more separate polities." 39

From an identity standpoint, the rest of Canada views Québec's presence as a fundamental part of national identity. Indeed, in a poll conducted in 1998, some 88 percent agreed that French-Canadians made significant contributions to Canada. About 77 percent of anglophones "hors Québec" wanted their children to be taught French at school and 61 percent said that having two official languages was important to the meaning of being Canadian. If language is to defined as a major marker of Canadian identity, it is in large part because of French, a language spoken by over 1.3 million persons outside Québec whose mother tongue is not French. ${ }^{40}$

\section{We the People}

A couple years after the referendum, Premier Bouchard stated that "[I]f English Canada wants

39 Alan. C. Cairns, "Looking into the Abyss: The Need for a Plan C" in David R. Cameron, ed., The Referendum Papers: Essays on Secession and National Unity (Toronto: University of Toronto Press, 1999) 199 at 219.

40 Chris Cobb, “Anglos outside Québec value French culture: poll” The Gazette (22 December 1998) A10. 
to hold a big contest to name us, we who are amenable, let them do it. It's a waste of time. We have to say it. We aren't interested in such a contest. We know what we are called. It's 'people of Québec'." ${ }^{41}$ As noted previously, in the early 1960s, the Royal Commission on Bilingualism and Biculturalism was mandated to recommend measures whereby the Canadian federation could be developed on the basis of an equal partnership between what was then referred to as its two founding peoples. Some thirty-five years later, the term "people" as employed in the Canadian context has multiple meanings. For some Québecers, the use of the term may be equated with nationhood. For others, people may still imply "ethnicity" or maybe viewed as a form of civic recognition. According to one major survey, it is the less politically-oriented idea of being a people that elicits a high rate of acknowledgement amongst Québecers independent of their mother tongue. ${ }^{42}$ So it would seem that while, for many, Québecers constitute a people, so too do Canadians. The same CROP poll shows that a vast majority of Québecers regard themselves as being part of at least these two peoples. ${ }^{43}$

\section{VIVE LE QUANADA!}

Kymlicka and Tully fail to address the issues that arise from those persons that have an attachment to more than one nation. Certainly, the ongoing debate over our constitutional future remains very much influenced by the issue of national identities. It is clear that over the past two decades, there has been a diminishing identification with Canada for a not insignificant number of the province's francophones. The extent to which one considers themselves a Canadian, Québecer, or both, is believed to be at the heart of the identity question. Public opinion polls have, in an effort to get to the bottom of the issue, obliged Québecers to decide whether they identified more with Québec or Canada. Often, the way in which a question is formulated on attachments to Québec and Canada has helped determine the outcome. Not surprisingly, such surveys have frequently uncovered an important

Philip Authier \& Terrance Wills, "Bouchard to Chretien: 'I dare you" The Gazette (26 September 1997) A1.

42 Paul Wells "Not a tale of two solitudes: poll" The Gazette (4 April 1998) A7.

43 Ibid. dichotomy along linguistic lines where a greater percentage of francophones chose Québec first while the overwhelming majority of nonfrancophones chose Canada. A CROP poll (March 27 to April 1, 1998) noted that some 80 percent of respondents saw themselves being both Québecers and Canadians, leading to the conclusion that they were "proud to be both Québecers and Canadians." ${ }^{\prime 4}$ A closer examination of the results, however, reveals that a slight majority of francophone respondents still viewed themselves as Québecers above all else (51 percent) and a near majority of anglophones see themselves as "Canadian First" (47 percent).

The reality regarding the Québec/Canada identity issue is frequently more complex than is revealed by numerous surveys. First, the respondents are invited to attribute their own meaning to the concept of national identity where there may be some confusion with the notion of ethnicity, citizenship and region. In effect, even the choice of being a "Québecer" first may simply imply that for some Canadians, "national" identification is less important than attachment to some ethno-national form of identity. After all, we know that respondents attribute different meanings to being a Québecer. In a series of articles in Le Devoir entitled "Pensez la nation québecoise," Jocelyn Létourneau argues that thinking about the future of Québec without taking into account the centrality of the Canadian fact as part of the identity of Québecers, is akin to thinking about the future of Canada while neglecting the centrality of the French fact to Canadian identity. ${ }^{46}$

In the event of a break-up, what would happen to the attachment to Canada felt by many Québecers? According to a former Québec Premier "nearly all non-francophones during the [1995] referendum reclaimed their desire to remain Canadian ... their interest dictates this attitude. Until a referendum is won they will stay as they are. Following that they will adapt. Until then they are Canadians and proud to be ... never will the Anglo-Québecers accept to exchange their attachment to a vast majority in Canada against

\footnotetext{
Ibid.

$45 \quad$ Ibid.

46 Jocelyn Létourneau, "Ni nation québécoise, ni nation candienne: Assumons l'identité dans sa complexité" Le Devoir (7 August 1999) A9.
} 
minority status in Québec." ${ }^{, 47}$ Of course it is not just Québec anglophones that feel an attachment to Canada. A sovereign Québec would still have to contend with a potentially strong sense of such identity and the political expression that it might take.

\section{A CRISIS OF IDENTITIES: QUÉBEC'S OWN ChARLOTTETOWN}

Those Québecers who are thinking about the nation are increasingly conscious of this reality and, as such, are developing their own recognition formulas in the event that sovereignty is attained. In some ways, the formulas put forth by the sovereignists resemble the models unsuccessfully pursued by the federal government. In what might be described as Québec sovereignists' version of the Charlottetown Accord, some call for the recognition of the francophone majority, the Aboriginal nations and the anglophone population as national minorities. Paradoxically, this implies that Québec itself is a multinational entity which risks being beset by the same problems as Canada. One thinker has suggested that a sovereign Québec recognize its three founding peoples (the francophones, anglophones and Aboriginals). ${ }^{48}$ Indeed, Denys Delâge contends that if it fails to provide such recognition, a sovereign Québec will confront the same identity problems that Canada does today. ${ }^{49}$ It is legitimate to ask whether these "peoples" would be vested with the right to selfdetermination. At the same time as Québec sovereignists attempt to give meaning within their project to the reality of diversity, they want the population to first see themselves as Québecers. According to a proposal developed by the leadership of the Bloc Québécois, “citizenship cannot be founded on such identity or community references as ethnicity, mother tongue and religion." ${ }^{50}$ The notion of belonging to the same political community and possessing a common civic reference - i.e. being Québecers - is the best response to growth of diversity. The Canadian

47 Jacques Parizeau, Pour un Québec souverain (Montreal: VLB Éditeur, 1997) at 163 [translated by author].

48 Denys Delâge, "Le Québec et les autochtones" in Michel Venne, ed., Penser la nation québécoise (Montréal: QuébecAmérique, 2000).

49 Ibid.

50 Pierre O’Neill, “Le Bloc Québécois relance le débat sur la redefinition du modéle québécois" Le Devoir (7 September 1999) A2. state continues to struggle with the issues of a strong sense of civic and national attachment and support for diversity and multiple identities. But there is ample reason to believe that a sovereign Québec will face equally important challenges involving recognition, inclusion and important manifestations of regional identity within its jurisdiction.

\section{AfFiRmation AND RECOGNITION}

In a recent series of essays entitled "Reinventing Our Future," La Presse's Alain Dubuc suggests that the debate over Québec identity should be pursued by Québecers alone. ${ }^{51}$ He proposes that Québecers engage in a process of unilateral affirmation or what might be described as self-definition. Dubuc believes that the rest of Canada does not need to approve the way in which Québecers describe themselves in identity terms. Indeed, he contends that the continued pursuit of such recognition is symptomatic of a sort of "colonized culture." This might be remedied by a unilateral affirmation of Québec's identity, which Dubuc suggests take the form of a solemn declaration by the National Assembly that enunciates the population's major characteristics. This strategy would only be practical if Québec's political parties resisted the temptation of using it as a negotiating tool draw the rest of Canada into yet another recognition debate. As to Dubuc's definition of Québecers' identity, he suggests that something between the terms "people" and "nation" be used, and that the presence of an anglophone minority, the contribution of immigrants, and the role of the First Nations be properly acknowledged. He rightly notes that coming up with a satisfactory formula will be no easy task as some will insist that attachment to Canada be included in the definition of Québec identity. ${ }^{52}$

One of the major contributions of Dubuc's idea is that it resituates the national unity debate in terms of the political relationship between affirmation and recognition. Some Québecers will insist that there have been several examples of affirmation on the part of Québec since the Quiet Revolution that have not been properly recognized by the rest of Canada. But in the rest of Canada,

\footnotetext{
51 “S'affirmer autrement" La Presse (24 February 2000) B3.

52 Ibid.
} 
some may consider that the onus for generating identity-based recognition formulas to indeed be on Québecers. These undoubtedly remain complex issues that will continue to underlie the Canadian identity crisis. As our identity needs continue to evolve both within Québec and throughout Canada, so too may the debate over how we affirm ourselves and the type of recognition that is desired by Canada's collectivities move in new directions.

Jack Jedwab, Ph.D.

Lecturer

McGill Institute for the Study of Canada

Executive Director

Association for Canadian Studies 